\title{
Incidence of Acute Coronary Syndrome in Elderly ICU Patients with Severe Head Trauma
}

\author{
AMR M. ABOU EL-KHEIR, M.Sc.; HALA S. EL-OZAIRY, M.D. and NOHA M. ELSHARNOUBY, M.D. \\ The Department of Anesthesiology, Intensive Care and Pain Management, Faculty of Medicine, Ain Shams University, \\ Cairo, Egypt
}

\begin{abstract}
Background: TBI is a worldwide health problem, which contributes to mortality and morbidity. Cardiac dysfunction has been reported after many neurologic injuries. Geriatric patients are more vulnerable to severe head trauma and developing acute coronary syndrome.

Aim of Study: This study aimed to determine the incidence of acute coronary syndrome in elderly ICU patients with severe head trauma.

Patients and Methods: This prospective cohort study was conducted on 47 elderly patients with isolated severe TBI, admitted to Emergency ICU Unit at Ain-Shams University Hospital. Heart rate and mean arterial blood pressure were monitored. Cardiac dysfunction was evaluated through studying ECG every 24 hours, serum cardiac troponin I on days 1 and 3 , echocardiography after 12 hours of admission and on days 3,5 and 7 and assessment of risk of mortality among patients with acute coronary syndrome by using GRACE score.
\end{abstract}

Results: By the end of the study period, acute coronary syndrome was reported in $36.2 \%$ of patients with $10.6 \%$ mortality. GRACE score was significantly associated with patient mortality in those who developed ACS and had 100\% sensitivity and $92 \%$ specificity in prediction of mortality among those patients at a cutoff value $>19$.

Conclusion: Cardiac dysfunction is not uncommon in elderly isolated traumatic brain injury patients with increased in-hospital mortality.

Key Words: Severe traumatic brain injury - Acute coronary syndrome - Echocardiography electrocardiogram - Troponin.

\section{Introduction}

TRAUMATIC Brain Injury (TBI) is defined as an alteration in brain function, or other evidence of brain pathology, caused by an external force [1]. It varies in severity from mild TBI to moderate and severe TBI [2]. TBI is one of the major causes of death and disability worldwide $[\mathbf{3 , 4}]$ and can be

Correspondence to: Dr. Amr M. Abou El-Kheir, E-Mail: amressa20@gmail.com considered as a silent epidemic [5]. Cardiac dysfunction has been reported after virtually every major injury to the neurologic system [6]. The pathophysiology of brain-heart interactions can be attributed mainly to excess catecholamines and three main factors are involved at the level of the brain, independent of the specific injury type: The location of the lesion, rises in intracranial pressure and the activation of the lower brain neuroendocrine pathways from the hypothalamus [7]. Elderly patients are at high risk of developing both traumatic brain injury $[\mathbf{8 , 9 ]}$ and acute coronary syndrome [10].

This study aimed to determine the incidence of acute coronary syndrome and related mortality in elderly ICU patients with severe head trauma.

\section{Patients and Methods}

After obtaining approval from Ethical Committee/Faculty of Medicine-Ain Shams University and obtaining written informed consents from patients legal guardians, 47 patients aged $\geq 50$ years old, admitted to Ain Shams University Emergency Hospital ICU with isolated severe TBI during the period from the beginning of July 2018 to the end of June 2019, were enrolled in this prospective, observational study.

Exclusion criteria were: History of cardiac morbidities, presence of chest or abdominal trauma, presence of long bone fractures, history of cardiac arrest before or within $24 \mathrm{~h}$ of ICU admission or presence of hemodynamic instability (hypovolemic, obstructive or septic).

After enrollment, all patients had a full history taken from the legal guardians including age, gender, past medical and surgical history. General 
examination was performed with special attention to head, neck and chest examination.

Continuous monitoring of heart rate "HR" and mean arterial blood pressure "MAP" was performed and patients were monitored for cardiac affection using assessment of serum troponin I, ECG and echocardiography. 12-lead ECG was performed daily (to detect abnormalities of ST segment and T-wave), cardiac troponin I (cTnI) was measured on days 1 and 3 and trans-thoracic echocardiography was performed within $12 \mathrm{~h}$ of admission and on days 3,5 and 7 .

Images for echocardiography were acquired in supine position, using ultrasound equipment (Vivid S5, GE Healthcare Company, USA) with a $2.5 \mathrm{Mhz}$ sector scanning electronic transducer. Images were obtained according to the standard and recommended procedure and based on the average of three cardiac-cycles. Images were acquired for conventional 2D and strain acquisition in cine loops triggered to the QRS complex and were stored in a cine-loop format of 1 cardiac cycle of uncompressed data with associated electrocardiogram information. Each echocardiography was digitally recorded under a randomized and anonymous number. At the conclusion of the study a subsequent blinded off-line analysis for conventional images was done, using a validated 2D software (EchoPac 6.0, GE Healthcare, Horten, Norway). All ultrasound parameters were analyzed blindly to clinical data [11].

The Global Registry of Acute Coronary Events (GRACE) score and its risk score were used to assess the risk of mortality among patients with acute coronary syndrome [12] after occurrence of the acute coronary syndrome event. The GRACE 2.0 ACS Risk Calculator implements the revised GRACE algorithms for predicting death or myocardial infarction following presentation with an ACS. Variables of GRACE score include age, heart rate, systolic blood pressure, serum creatinine, Killip classification which includes (class 1: No congestion signs, class 2: $\mathrm{S} 3$ and basal rales, class 3: Acute pulmonary edema and class 4: Cardiogenic shock), cardiac arrest at admission, elevated cardiac markers, ST-segment deviation \}, then GRACE score and its risk score were calculated online at the site https://www.outcomes-umassmed. org/ grace/acs_ri sk2/index.html.

Primary outcome was to calculate the incidence of acute coronary syndrome in elderly patients with isolated TBI, whereas the secondary outcome included incidence of morbidity and mortality as predicted by GRACE score.

\section{Statistical analysis:}

Sample size was calculated to be 47 critical care patients using PASS program, setting alpha error at $5 \%$ and confidence interval width at 0.24 with a result from a previous study which showed that abnormal ECG was present in $28 \%$ of cases with TBI [9].

Data were collected, revised, coded, tabulated and analyzed using the Statistical Package for Social Science (IBM SPSS) version 23. Quantitative data were presented as mean, standard deviations and ranges in case of normally distributed data or median, interquartile range and range in case of abnormally distributed data and One Way ANOVA test was used for comparison between groups in this case. Meanwhile, qualitative variables were presented as number and percentages, Chisquare testwas used for comparison between groups of qualitative variables and Fisher exact test was used when the expected count in any cell was found to be less than 5 . The confidence interval was set to $95 \%$ and the margin of error accepted was set to $5 \%$. So, the $p$-value was considered significant at the level of $<0.05$.

\section{Results}

Ninety-four patients were admitted to emergency ICU with TBI over a period of 12 months. Eighty-two patients were enrolled in the study. Thirty patients were excluded due to presence of other injuries and five patients were excluded due to being below 50 years old. Forty-seven patients were thus included in the study.

The age of the patients ranged between 51 and 78 years with a mean age of 64.04 (6.19) years, $72.3 \%$ of the patients were males and $27.7 \%$ were females. $10.6 \%$ of the patients had a history of hypertension and diabetes, $8.5 \%$ had a history of hypertension, $4.3 \%$ had a history of diabetes and $19.1 \%$ had a positive history of previous surgery. Glasgow coma score of the included patients ranged between 4 and 8 with a median of 7 with its $95 \%$ confidence interval value between 6.42 and 7.06 (Table 1).

The mean heart rate in the study group steadily decreased over time from the day of admission to day 7 post-admission. The reduction in mean heart rate was overall statistically significant $(p=0.000)$. The HR in 12 hours post admission was increased insignificantly $(p=1.000)$ in comparison with the HR on admission. The HR in 24 hours was decreased significantly ( $p=0.037)$, and it continued to decrease significantly in days $3(p=0.004), 5$ 
$(p=0.001)$ and $7(p=0.000)$ in comparison with the HR on admission (Table 2).

The mean arterial blood pressure in the study group decreased significantly from its value on admission to a mean value of $86.8(5.04) \mathrm{mmHg}$ at 12 -hours post-admission $(p=0.020)$. The mean arterial blood pressure then increased insignificantly to be 90.62 (7.48) $\mathrm{mmHg}$ at 24 hours postadmission $(p=0.238)$ and then it decreased insignificantly again to be 86.91 (6.72) $\mathrm{mmHg}$ at 3 days post-admission $(p=1.000)$. After this, the MAP continued to decrease significantly to reach 85.02 (6.90) $\mathrm{mmHg}$ at 5 days post admission $(p=0.045)$, 84.57 (3.70) $\mathrm{mmHg}$ at 7 days post-admission $(p=$ 0.000 ) in comparison with the mean arterial blood pressure on admission (Table 3 ).

$38.1 \%$ of survivors had abnormal ECG changes on admission and their ratio remained the same in 24-hour, days 2, 3, 4, 5, 6 and 7. $100 \%$ of non survivors had abnormal ECG changes on admission till day 6 , with a statistically significant difference between normal and abnormal ECG among survivors and non survivors at each time point till day $6(p=0.008)$ (Table 4). Abnormal ECG changes that occurred from admission to day 6 postadmission were in the form of: Depressed ST in $42.9 \%$ of patients with abnormal ECG changes, elevated ST (19\%), hyperacute T (19\%) and other abnormalities (19\%).

$35.7 \%$ of survivors compared to $80 \%$ of non survivors had elevated cardiac troponin at 24-hours post admission, with no statistically significant difference between groups ( $p=0.056)$. At 72 hours post admission, $40.5 \%$ of survivors compared to $80 \%$ of non survivors had elevated cardiac troponin $(p=0.093)$ (Table 5).

At 12-hours and 3 days post admission, $4.8 \%$ of survivors had abnormal Echo findings compared to $60 \%$ and $80 \%$ of non survivors respectively, with a statistically significant difference $(p=0.000)$. At 5 and 7 days post admission, $7.1 \%$ of survivors compared to $80 \%$ of non-survivors with statistically significant difference between study groups $(p=$ 0.000) (Table 6).

By the end of the study period, acute coronary syndrome was reported in $36.2 \%$ of patients included in the study Fig. (1) and mortality was reported in $10.6 \%$ of patients.

There was statistically significant increase of total GRACE score and its risk score in patients who died due to ACS when compared to those who survived, although they developed ACS (Table 7).
When running ROC curve analysis, the Area Under the Curve (AUC) for GRACE was 0.97 denoting the good predictability of the test for mortality among studied population. The cut of value was $>19$, with sensitivity of $100 \%$ and specificity of $92 \%$ Fig. (2).

Table (1): Patients characteristics and glasgow coma scale of the study group.

\begin{tabular}{ll}
\hline & \multicolumn{1}{c}{ No.=47 } \\
\hline Age (yr): & \\
Mean (SD) & $64.04(6.19)$ \\
Range & $51-78$ \\
Gender No. (\%): & \\
Female & $13(27.7 \%)$ \\
Male & $34(72.3 \%)$ \\
History chronic disease No. (\%): & \\
HTN & $4(8.5 \%)$ \\
DM & $2(4.3 \%)$ \\
HTN + DM & $5(10.6 \%)$ \\
Previous surgery No. (\%): & \\
Negative & $38(80.9 \%)$ \\
Positive & $9(19.1 \%)$ \\
Glasgow coma score (GCS): & \\
Median (IQR) & $7(6-8)$ \\
Range & $4-8$ \\
95\% confidence interval & $6.42-7.06$ \\
\hline
\end{tabular}

- Data are presented as mean and SD and numbers and percentage as well as median and range.

Table (2): Heart rate in the study group.

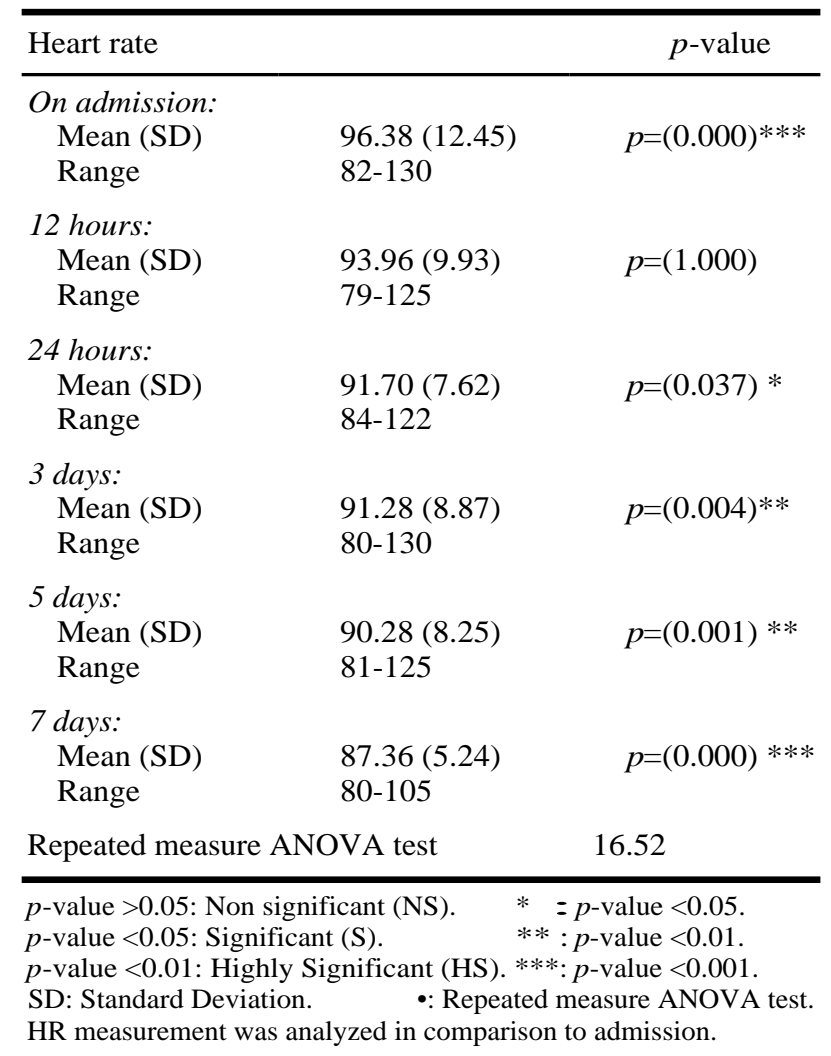


Table (3): MAP (Mean Arterial Pressure) in the study group.

\begin{tabular}{|c|c|c|}
\hline \multicolumn{2}{|l|}{ MAP } & $p$-value \\
\hline $\begin{array}{l}\text { On admission: } \\
\text { Mean (SD) } \\
\text { Range }\end{array}$ & $\begin{array}{l}88.53(5.52) \\
82-102\end{array}$ & $p=(0.000) * * *$ \\
\hline $\begin{array}{l}12 \text { hours: } \\
\text { Mean (SD) } \\
\text { Range }\end{array}$ & $\begin{array}{l}86.81(5.04) \\
80-100\end{array}$ & $p=(0.020)^{*}$ \\
\hline $\begin{array}{l}24 \text { hours: } \\
\text { Mean (SD) } \\
\text { Range }\end{array}$ & $\begin{array}{l}90.62(7.48) \\
81-109\end{array}$ & $p=(0.238)$ \\
\hline $\begin{array}{l}3 \text { days: } \\
\text { Mean (SD) } \\
\text { Range }\end{array}$ & $\begin{array}{l}86.91(6.72) \\
70-110\end{array}$ & $p=(1.000)$ \\
\hline $\begin{array}{l}5 \text { days: } \\
\text { Mean (SD) } \\
\text { Range }\end{array}$ & $\begin{array}{l}85.02(6.90) \\
70-112\end{array}$ & $p=(0.045)^{*}$ \\
\hline $\begin{array}{l}7 \text { days: } \\
\text { Mean (SD) } \\
\text { Range }\end{array}$ & $\begin{array}{l}84.57(3.70) \\
81-100\end{array}$ & $p=(0.000) * * *$ \\
\hline Repeated meas & VA test & 12.060 \\
\hline
\end{tabular}

Table (4): ECG changes in the study group.

\begin{tabular}{|c|c|c|c|c|c|c|}
\hline & \multicolumn{4}{|c|}{ Survivors Non survivors } & \multirow{2}{*}{$\begin{array}{c}\text { Test } \\
\text { value* }\end{array}$} & \multirow{2}{*}{$\begin{array}{c}p- \\
\text { value }{ }^{* *}\end{array}$} \\
\hline & No. & $\%$ & No. & $\%$ & & \\
\hline $\begin{array}{l}\text { Admission: } \\
\text { Normal } \\
\text { Abnormal }\end{array}$ & $\begin{array}{l}26 \\
16\end{array}$ & $\begin{array}{l}61.9 \\
38.1\end{array}$ & $\begin{array}{l}0 \\
5\end{array}$ & $\begin{array}{l}0.0 \\
100.0\end{array}$ & 6.927 & $p=(0.008)$ \\
\hline $\begin{array}{l}\text { 24h: } \\
\text { Normal } \\
\text { Abnormal }\end{array}$ & $\begin{array}{l}26 \\
16\end{array}$ & $\begin{array}{l}61.9 \\
38.1\end{array}$ & $\begin{array}{l}0 \\
5\end{array}$ & $\begin{array}{l}0.0 \\
100.0\end{array}$ & 6.927 & $p=(0.008)$ \\
\hline $\begin{array}{l}2 \text { day: } \\
\text { Normal } \\
\text { Abnormal }\end{array}$ & $\begin{array}{l}26 \\
16\end{array}$ & $\begin{array}{l}61.9 \\
38.1\end{array}$ & $\begin{array}{l}0 \\
5\end{array}$ & $\begin{array}{l}0.0 \\
100.0\end{array}$ & 6.927 & $p=(0.008)$ \\
\hline $\begin{array}{l}3 \text { day: } \\
\text { Normal } \\
\text { Abnormal }\end{array}$ & $\begin{array}{l}26 \\
16\end{array}$ & $\begin{array}{l}61.9 \\
38.1\end{array}$ & $\begin{array}{l}0 \\
5\end{array}$ & $\begin{array}{l}0.0 \\
100.0\end{array}$ & 6.927 & $p=(0.008)$ \\
\hline $\begin{array}{l}4 \text { day: } \\
\text { Normal } \\
\text { Abnormal }\end{array}$ & $\begin{array}{l}26 \\
16\end{array}$ & $\begin{array}{l}61.9 \\
38.1\end{array}$ & $\begin{array}{l}0 \\
5\end{array}$ & $\begin{array}{l}0.0 \\
100.0\end{array}$ & 6.927 & $p=(0.008)$ \\
\hline $\begin{array}{l}5 \text { day: } \\
\text { Normal } \\
\text { Abnormal }\end{array}$ & $\begin{array}{l}26 \\
16\end{array}$ & $\begin{array}{l}61.9 \\
38.1\end{array}$ & $\begin{array}{l}0 \\
5\end{array}$ & $\begin{array}{l}0.0 \\
100.0\end{array}$ & 6.927 & $p=(0.008)$ \\
\hline $\begin{array}{l}6 \text { day: } \\
\text { Normal } \\
\text { Abnormal }\end{array}$ & $\begin{array}{l}26 \\
16\end{array}$ & $\begin{array}{l}61.9 \\
38.1\end{array}$ & $\begin{array}{l}0 \\
5\end{array}$ & $\begin{array}{l}0.0 \\
100.0\end{array}$ & 6.927 & $p=(0.008)$ \\
\hline $\begin{array}{l}7 \text { day: } \\
\text { Normal } \\
\text { Abnormal }\end{array}$ & $\begin{array}{l}26 \\
16\end{array}$ & $\begin{array}{l}61.9 \\
38.1\end{array}$ & $\begin{array}{l}0 \\
0\end{array}$ & $\begin{array}{l}0.0 \\
0.0\end{array}$ & NA & NA \\
\hline $\begin{array}{c}* \text { : Fisher exact } \\
p \text {-value }<0.05 \text { : } \\
p \text {-value }<0.01: \\
\text { NA: Non Appl } \\
\text { ECG chan }\end{array}$ & $\begin{array}{l}\text { test. } \\
\text { Signif } \\
\text { Highly } \\
\text { icable. }\end{array}$ & y Sig & $p$-valu & $\begin{array}{l}\text { e }>0.05: \mathrm{N} \\
\text { HS). }\end{array}$ & $\begin{array}{r}\text { Non signif } \\
* *: p- \\
\text { al and ab }\end{array}$ & $\begin{array}{l}\text { ficant (NS). } \\
\text { value }<0.01 \text {. }\end{array}$ \\
\hline
\end{tabular}

Table (5): Serum cardiac Troponin I in the study group.

\begin{tabular}{lccccccc}
\hline Troponin I & \multicolumn{2}{c}{ Survivors } & \multicolumn{2}{c}{ Non survivors } & Test & $\begin{array}{c}p \text { - } \\
\text { value }\end{array}$ & value \\
\cline { 2 - 5 } & No. & $\%$ & No. & $\%$ & & \\
\hline 24 hours: & & & & & & \\
$\quad$ Normal & 7 & 64.3 & 1 & 20.0 & 3.639 & 0.056 \\
$\quad$ Elevated & 5 & 35.7 & 4 & 80.0 & & \\
72 hours: & & & & & & \\
$\quad$ Normal & 5 & 59.5 & 1 & 20.0 & 2.824 & 0.093 \\
Elevated & 7 & 40.5 & 4 & 80.0 & & \\
\hline
\end{tabular}

*: Chi-square test. $p$-value $<0.05$ : Significant (S).

$p$-value $<0.01$ : Highly Significant (HS).

Cardiac Troponin was analyzed between normal and elevated study groups in relation to mortality.

Table (6): Echocardiography findings in the study group.

\begin{tabular}{|c|c|c|c|c|c|c|}
\hline \multirow{2}{*}{ Echo } & \multicolumn{4}{|c|}{ Survivors Non survivors } & \multirow{2}{*}{$\begin{array}{c}\text { Test } \\
\text { value }\end{array}$} & \multirow{2}{*}{$\begin{array}{c}p- \\
\text { value }\end{array}$} \\
\hline & No. & $\%$ & No. & $\%$ & & \\
\hline \multicolumn{7}{|l|}{12 hours: } \\
\hline Normal & 40 & 95.2 & 2 & 40.0 & \multirow[t]{2}{*}{14.341} & \multirow[t]{2}{*}{$p=(0.000)$} \\
\hline Abnormal & 2 & 4.8 & 3 & 60.0 & & \\
\hline \multicolumn{7}{|l|}{3 days: } \\
\hline Normal & 40 & 95.2 & 1 & 20.0 & \multirow[t]{2}{*}{22.712} & \multirow[t]{2}{*}{$p=(0.000)$} \\
\hline Abnormal & 2 & 4.8 & 4 & 80.0 & & \\
\hline \multicolumn{7}{|l|}{5 days: } \\
\hline Normal & 39 & 92.9 & 1 & 20.0 & \multirow[t]{2}{*}{18.711} & \multirow[t]{2}{*}{$p=(0.000)$} \\
\hline Abnormal & 3 & 7.1 & 4 & 80.0 & & \\
\hline \multicolumn{7}{|l|}{7 days: } \\
\hline Normal & 39 & 92.9 & 0 & 0.0 & \multirow[t]{2}{*}{ NA } & \multirow[t]{2}{*}{ NA } \\
\hline Abnormal & 3 & 7.1 & 0 & 0.0 & & \\
\hline
\end{tabular}

*: Chi-square test. $p$-value $>0.05$ : Non Significant (NS). $p$-value $<0.05$ : Significant (S). NA: Non Applicable. $p$-value $<0.01$ : Highly Significant (HS). $\quad * * *: p$-value $<0.001$.

Echo findings were analyzed between normal and abnormal study groups in relation to mortality.

Table (7): GRACE score among studied patients with ACS.

\begin{tabular}{|c|c|c|c|}
\hline & $\begin{array}{c}\text { Survivors } \\
\text { No. }=13\end{array}$ & $\begin{array}{c}\text { s Non survivors } \\
\text { No. }=4\end{array}$ & $\begin{array}{c}\text { s Test } \quad p- \\
\text { value } \neq \text { value }\end{array}$ \\
\hline $\begin{array}{l}\text { Total grace: } \\
\text { - Median (IQR) } \\
\text { - Range }\end{array}$ & $\begin{array}{l}44(31-58) \\
23-187\end{array}$ & $\begin{array}{l}207(186-234) \\
184-242\end{array}$ & $\begin{array}{l}-2.831 p= \\
0.005 * *\end{array}$ \\
\hline $\begin{array}{l}\text { Grace risk: } \\
\text { - Median (IQR) } \\
\text { - Range }\end{array}$ & $\begin{array}{l}8.4(5.9-11) \\
4.4-36\end{array}$ & $\begin{array}{l}39.5(35.5-44.5) \\
35-46\end{array}$ & $\begin{array}{l}-2.776 p= \\
0.006 * *\end{array}$ \\
\hline
\end{tabular}

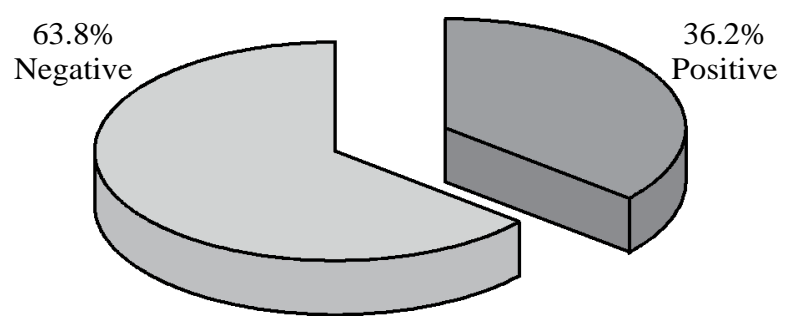

Fig. (1): ACS in the study population. 


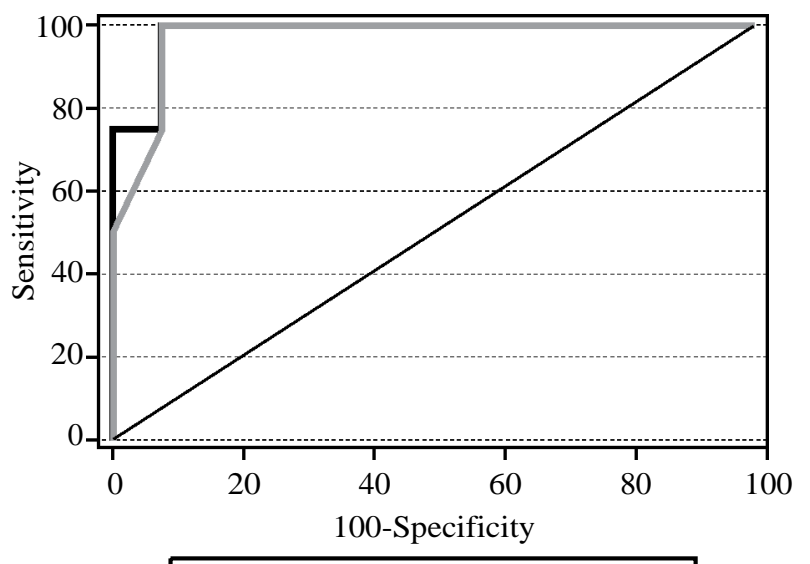

Total Grace

Grace risk

Fig. (2): ROC curve for Grace in prediction of mortality.

\section{Discussion}

In this study, ACS was reported in $36.2 \%$ of elderly patients with severe TBI, with $10.6 \%$ mortality reported by the end of the study period. GRACE score and its risk score were significantly associated with patient mortality in those who developed ACS. GRACE score had 100\% sensitivity and $92 \%$ specificity in prediction of mortality among patients who developed ACS after isolated severe TBI at a cutoff value $>19$.

This study showed statistically significant difference between normal and abnormal ECG in survivors compared to deceased group. Abnormal ECG in survivors group maintained a ratio of $38.1 \%$ from admission till 7 days post admission. $100 \%$ of deceased group had abnormal ECG changes on admission and maintained this ratio till day 6. Abnormal ECG changes were in the form of depressed ST in $42.9 \%$ of patients with abnormal ECG changes, elevated ST (19\%), hyper acute T $(19 \%)$ and other abnormalities (19\%).

Dzudie et al. [13] in his study showed that some of ECG abnormalities were associated with a higher risk for adverse outcome in these patients. Vaclavik et al., [14] study confirmed the high prevalence rates of abnormal ECG and the fact that some of the abnormalities were associated with more adverse outcome.

In a study by Diab et al., [10], ECG changes in ACS group were in the form of ST elevation in (33.3\%), ST depression in (55.6\%) and hyper acute $\mathrm{T}$ wave in $(11.1 \%)$. Also, Gregory and Smith [15] demonstrated that ECG abnormalities after TBI such as ST segment depression and abnormal T waves can be associated with the development of a delayed ischemic neurological deficit, poor outcome, and death.
In this study, we found no statistically significant difference between normal and elevated cardiac troponin I among survivors and deceased groups at 24-hours post admission.

In accordance with our results, Serri et al., [16] reported no significant association between Troponin and the mortality of the studied patients.

On the other hand, some studies revealed that the degree of severity of overall body injury is reflected on the magnitude of troponin level elevation following trauma and supported the prognostic value and the merit of cTnI data in patients with TBI [17-20].

The current study revealed a statistically significant difference between normal and abnormal echo among survivors and non-survivors at 12 hours, 3,5 and 6 days post admission.

These findings differ from those reported in Prathep et al., [8] study that was performed on 139 isolated TBI patients in which $22.3 \%$ of patients had abnormal echocardiogram and Hasanin et al., [9] who reported abnormal echocardiographic examination in $(28 \%)$ of patients developed cardiac injury after TBI. This difference can be attributed to different patient characteristics including age (mean age of $58 \pm$ (20) years in contrast to 64.04 \pm (6.19) years in this study, type and degree of trauma and associated comorbidities.

The present study revealed that acute coronary syndrome was reported in $36.2 \%$ of patients included in the study. Meanwhile, mortality was reported in $10.6 \%$ of patients by the end of the study period. This mortality percent agrees with previous studies [10,21,22].

On the other hand, other studies reported higher mortality percentage. Jochems et al., [23] reported a mortality rate of $33.0 \%$ during hospitalization. Caiet et al., [17] reported a mortality rate of $49.5 \%$. This higher rate of mortality could be attributed to different sample size, the type of trauma or the pre-existing cardiac disease. A higher mortality rate of $65.7 \%$ was reported in the study performed by Rimaz et al., [20] and this difference might be explained by the higher percentage of patients with cardiac affection.

The present study revealed a significantly higher total GRACE score and its risk score in patients who died due to ACS when compared to those who survived, although they developed ACS. Furthermore, we found that a GRACE at a cutoff value $>19$ had a sensitivity of $100 \%$ and specificity of 
$92 \%$ in predication of mortality among patients who developed acute coronary syndrome.

These results come in line with those published in Abu-Assie et al., [24] study that was performed on 5985 patients in which GRACE risk scores demonstrated excellent discrimination in prediction of in-hospital mortality in case of ACS patients.

\section{Conclusion:}

Cardiac dysfunction is not uncommon in isolated traumatic brain injury cases and might be associated with increased in-hospital mortality.

\section{Limitations:}

One of the limitations of this study is its singlecenter basis. Another limitation is that association between cardiac dysfunction and mortality was not confirmed.

\section{Recommendations:}

This finding raises the question as to whether there are uncharted opportunities for a more timely recognition of cardiac dysfunction and subsequent optimization of the hemodynamic management of these patients. So, further research with larger sample size is necessary to evaluate cardiac dysfunction in neurologic injuries, to better understand the impact of TBI on cardiac dysfunction and on patient outcomes and to test therapeutic strategies that may either prevent or attenuate the development of neurogenic cardiac dysfunction.

\section{Conflict of interest:}

None.

\section{References}

1- MENON D.K., SCHWAB K., WRIGHT D.W. and MAAS A.I.: Position statement: Definition of traumatic brain injury. Arch. Phys. Med. Rehabil., 91: 1637-40, 2010.

2- ROSENFELD J.V., MAAS A.I., BRAGGE P., MORGANTI-KOSSMANN M.C., MANLEY G.T., et al.: Early management of severe traumatic brain injury. Lancet, 380: 1088-98, 2012.

3- CARNEY N., TOTTEN A.M., O'REILLY C., ULLMAN J.S., HAWRYLUK G.W., et al.: Guidelines for the management of severe traumatic brain injury, fourth edition. Neurosurgery, 80 (1): 6-15, 2017.

4- FEIGIN V.L., THEADOM A., BARKER-COLLO S., STARKEY N.J., McPHERSON K., et al.: Incidence of traumatic brain injury in New Zealand: A populationbased study. Lancet Neurol., 12 (1): 53-64, 2013.

5- DEWAN M.C., RATTANI A., GUPTA S., BATICULON R.E., HUNG Y.C., et al.: Estimating the global incidence of traumatic brain injury. J. Neurosurg., 1: 1-18, 2018.

6- PORTO I., DELLA-BONA R. and LEO A.: Stress cardiomyopathy (tako-tsubo) triggered by nervous system diseases: A systematic review of the reported cases. Int. J. Cardiol., 167 (6): 2441-8, 2013.

7- KRISHNAMOORTHY V., MACKENSEN G., GIBBONS E. and VAVILALA M.: Cardiac dysfunction after neurologic injury: What do we know and where are we going? Chest, 149 (5): 1325-31, 2016.

8- PRATHEP S., SHARMA D., HALLMAN M., JOFFE A., KRISHNAMOORTHY V., et al.: Preliminary report on cardiac dysfunction after isolated traumatic brain injury. Crit. Care Med., 42: 142-7, 2014.

9- HASANIN A., KAMAL A., AMIN S., et al.: Incidence and outcome of cardiac injury in patients with severe head trauma. Scand J. Trauma. Resusc. Emerg. Med., 24: $58,2016$.

10- DIAB A.E., HUSSEIN M.H., AHMED A.A., et al.: Incidence of acute coronary syndrome after traumatic brain injury in intensive care unit (Associated factors and mortality) A retrospective study. Egypt J. Forensic. Sci. Appli. Toxicol., 20 (1): 1-14, 2020.

11- LANG R.M., BADANO L.P., MOR-AVI V., AFILALO J., ARMSTRONG A., et al.: Recommendations for cardiac chamber quantification by echocardiography in adults: An update from the American Society of Echocardiography and the European Association of Cardiovascular Imaging. J. Am. Soc. Echocardiogr., 28 (1): 1-39, 2015.

12- GRANGER C.B., GOLDBERG R.J., DABBOUS O., EAGLE K.A., CANNON C.P., et al.: Predictors of hospital mortality in the global registry of acute coronary events. Arch. Intern. Med., 163: 19: 2345-53, 2003.

13- DZUDIE A., MILO O., EDWARDS C., et al.: Prognostic Significance of ECG Abnormalities for Mortality Risk in Acute Heart Failure: Insight From the Sub-Saharan Africa Survey of Heart Failure (THESUS-HF). Journal of Cardiac Failure, 20 (1): 45-52, 2014.

14- VACLAVIK J., SPINAR J., VINDIS D., VITOVEC J., WIDIMSKY P., CIHALIK C., et al.: ECG in patients with acute heart failure can predict in-hospital andlong-term mortality. Intern. Emerg. Med., 9 (3): 283-91, 2014.

15- GREGORY T. and SMITH M.: Cardiovascular complications of brain injury, Continuing Education in Anaesthesia Critical Care \& Pain, 12 (2): 67-71, 2012.

16- SERRI K., EL RAYES M., GIRALDEAU G., WILLIAMSON D. and BERNARD F.: Traumatic brain injury is not associated with significant myocardial dysfunction: An observational pilot study. Scand J. Trauma Resusc. Emerg. Med., 24 (1): 31. doi:10.1186/513049-016-0217-4, 2016.

17- CAI S.S., BONDS B.W., HU P.F. and STEIN D.M.L.: The role of cardiac troponin I in prognostication of patients with isolated severe traumatic brain injury. J. Trauma Acute Care Surg., 80: 477-83, 2016.

18- EL-MENYAR A., SATHIAN B., WAHLEN B. and ALTHANI B.: Serum cardiac troponins as prognostic markers in patients with traumatic and non-traumatic brain injuries: A meta-analysis. American Journal of Emergency Medicine, 37 (1): 133-42, 2019.

19- SALIM A., HADJIZACHARIA P., BROWN C., INABA K., TEIXEIRA P.G., CHAN L., et al.: Significance of troponin elevation after severe traumatic brain injury. J. Trauma, 64 (1): 46-52, 2008. 
20- RIMAZ S., ASHRAF A., MARZBAN S., HAGHIGHI M., ZIABARI S., et al.: Significance of cardiac troponin I elevation in traumatic brain injury patients. Anesth Pain Med., 9(2): e90858. doi: 10.5812/aapm.90858, 2019.

21- KRISHNAMOORTHY V., ROWHANI RAHBAR A., CHAIKITTISILPA N., GIBBONS E., RIVARA F., et al.: Association of early hemodynamic profile and the development of systolic dysfunction following traumatic brain injury. Neurocrit. Care, 26: 379-87, 2017.

22- URDANETA A., FINK K., ROWHANI RAHBAR A., ROWHANI RAHBAR A.3, VAVILALA M., et al.: Radiographic and Clinical Predictors of Cardiac Dysfunction
Following Isolated Traumatic Brain Injury. Journal of Intensive Care Medicine, 32 (2): 151-7, 2017.

23- JOCHEMS D., VAN WESSEM K. and HOUWERT R.: Outcome in Patients with Isolated Traumatic Brain Injury. Hindawi Critical Care Research and Practice, 2018: 3769418: https://doi.org/10.1155/2018/3769418, 2018.

24- ABU-ASSI E., FERREIRA-GONZÁLEZ I., RIBERA A., MARSAL J., CASCANT P., et al.: Do GRACE (Global Registry of Acute Coronary events) risk scores still maintain their performance for predicting mortality in the era of contemporary management of acute coronary syndromes? Am. Heart J., 160: 826-34, 2010.

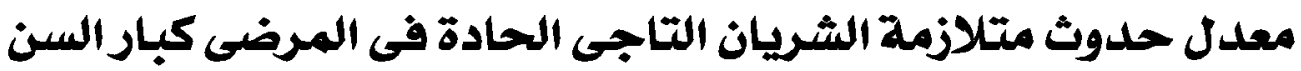

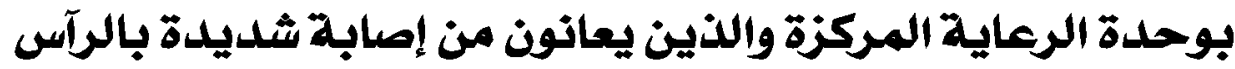

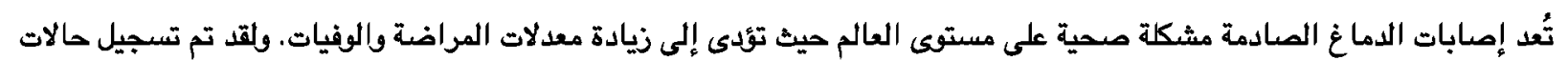

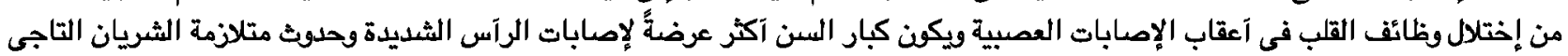
الحادة. وتهذف هذه الدراسة إلى تحديد معدل حدوث متلازمة الشريان التاجى الحادة لدى المرضى المعان المسنين بوحدة العناية المركزة المصابين بصدمات شديدة فى الرآس.

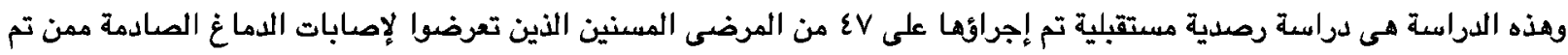

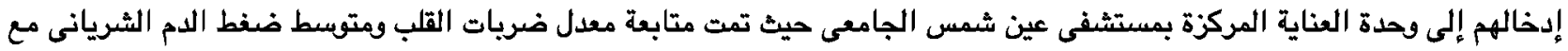

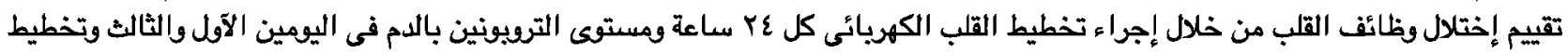

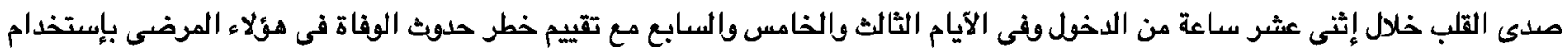
مؤشر جرايس (GRACE).

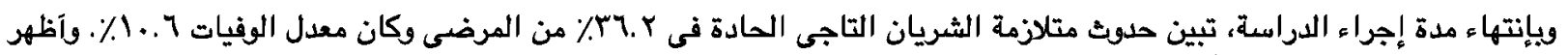

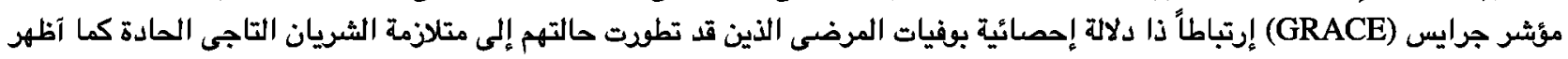

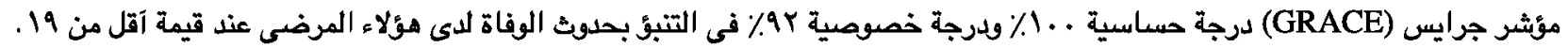
وخلمت الدراسة إلى آن إختلال وظائف القلب شائع الحدوث بين المرضى المسنين الذين يتعرضون لإصابات الرآس الصادمة مع زيادة إحتمالية الوفاة لدى هؤلاء المرضى آثثاء وجودهم بالمستشفى. 